\title{
Erratum to: The journey of tandem running: the twists, turns and what we have learned
}

\author{
E. L. Franklin
}

Published online: 11 December 2013

(C) International Union for the Study of Social Insects (IUSSI) 2013

\section{Erratum to: Insect. Soc.}

\section{DOI 10.1007/s00040-013-0325-3}

Unfortunately, there are three entries missing in the published Table 1. Missing entries are listed below.

Table 1 A table of all the identified instances and contexts of tandem running throughout the Myrmicinae, Formicinae and Ponerinae subfamilies of ants

\begin{tabular}{llll}
\hline Subfamily & Species or Genera & $\begin{array}{l}\text { Tandem } \\
\text { running } \\
\text { recruitment } \\
\text { context }\end{array}$ & Reference \\
\hline Ponerinae & $\begin{array}{c}\text { Pachycondyla } \\
\text { obscuricornis }\end{array}$ & Food & $\begin{array}{c}\text { Hölldobler and } \\
\text { Traniello } \\
\text { Myrmicinae }\end{array}$ \\
& $\begin{array}{l}\text { Temnothorax rugatulus } \\
\text { Temnothorax } \\
\text { curvispinosus }\end{array}$ & $\begin{array}{c}\text { Food and } \\
\text { nest }\end{array}$ & $\begin{array}{c}\text { Pratt 2008 } \\
\end{array}$ \\
& & & \\
\hline
\end{tabular}

The online version of the original article can be found under doi:10.1007/s00040-013-0325-3.

E. L. Franklin $(\bowtie)$

School of Applied Sciences, Bournemouth University,

Christchurch House, Talbot Campus, Fern Barrow,

Poole, Dorset BH12 5BB, UK

e-mail: efranklin@bournemouth.ac.uk 